Јелена Ј. ЈОВАНОВИЋ СИМИЋ*

Универзитет у Београду

Филолошки факултет

Катедра за српски језик са јужнословенским језицима

\title{
СТРУКТУРА И ФУНКЦИЈА ВРЕМЕНСКИХ ОБЛИКА У НАРОДНОЈ ПРИЧИ*
}

\begin{abstract}
Аутор у овом истраживању полази са платформе својих вербатолошких налаза до којих је дошао у Вербатологији (Јовановић Симић, Симић 2015). Та истраживања показала су да су за упознавање природе глаголских времена од значаја не само реченица, у којој лични глаголски облик чини језгро, већ и шири текстовни облици: жанрови и начини излагања (као и функционално стилски облици). Са тога гледишта обављена је анализа извесног броја народних приповедака и између осталог праћена њихова улога у изградњи текстовних облика и стилских особености.

Кључне речи: вербатив, стил, народна приповетка, временски облик.
\end{abstract}

\section{1. Увод}

1. Наука о значењу и употреби глаголских облика нпр. у Белићевим истраживањима везана је за науку о реченици, и ово двоје посматрано је као јединствен комплекс проблема (в.: Симић 1966: 2). Пошто „лични глаголски облици претстављају целе и потпуне реченице” (Белић 1998: 35), „а пошто је немогуће одвојити значење глаголских облика од њихове употребе” (,Јер од употребе зависи њихово значење” - Белић 2000: 219-220); те „да би се могло добити одређивање правог времена, мора се значење глагола остварити, реализовати" (Белић 1998: 200). То значи да се реализација значења глаголских облика дешава заправо у реченици. „Положај у реченици и функција предиката учинили су да оне особине које се код глагола јављају у предикату постану саставни део глаголске природе, то је обележје времена, глаголског начина и, како се обично вели, глаголског рода" (Белић 1998: 200). Ван видика је

\footnotetext{
*jelenajo@bitsyu.net

** Овај рад је написан у оквиру пројекта Српски језик и његови ресурси: теорија, опис и примене (178006), који финансира Министарство просвете, науке и технолошког развоја Републике Србије.
} 
остала чињеница да знак не може функционисати ad hoc, већ у сплету солидарности и супротности са осталим знаковима не само у исказним формама - на тзв. парадигматском плану, - већ тек посредством солидарности и супротности у систему којем припада. Тек сталним кретањем између та два амбијента он може живети пуним животом. Уколико остаје неактиван, дакле ван употребе у споразумевању, он полако губи своје ингеренције (исп. проблем архаизације лексичких јединица, облика или сл.), и одумире. Исто тако би био нежив ако би се нашао у исказној форми а да нема приступа систему (сетимо се непознатих речи у тексту или сл.).

2. И још нешто је вредно пажње. Поставивши у жижу посматрања реченицу и искључивши све што се дешава ван ње, нпр. између реченица, и шире на међуисказном простору, - истраживачи ове оријентације ускратили су себи могућност да језички знак сагледају у тексту као широј целини и његову улогу као фактора изградње и квалитативних својстава тих ширих, да кажемо текстовних целина. Старији истраживачи, Т. Маретић и А. Мусић (а у неком смислу касније и М. Стевановић), зачудо нису били ограничени каснијим лингвистичким назорима, него воде расправу о употреби глаголских облика у условима које чине, прво, различите врсте текста, и друго, различите врсте излагања ${ }^{1}$. И треће: и једно и друго варира с обзиром на подручне и друштвене варијације језика. Но и Маретић и Мусић схватили су ове дистинкције донекле механички, пратећи само квантитативне, а не и квалитативне моменте.

а) Што се тиче првог и трећег, Маретић (1963: 616) нпр. овако резонује о употреби пређашњих времена:

\footnotetext{
„У јужним крајевима” ови су облици чести „у обичном говору, а у осталим крајевима слабо. То се лијепо види из Вукових народних приповједака, гдје су ова два облика много обичнија у приповијеткама из јужних крајева неголи у онима које су из источних. У народним пјесмама (које не приказују вјерно обични говор) врло су обични и аорист и имперфект, - и ја мислим да се у много случајева узимају та два времена поради потреба стиха, тј. ондје гдје стих не допушта узети перфект, па је аналогија такових стихова учинила те су аорист и имперфект продрли и у стихове у којима би могао (с обзиром на број слогова) стајати и перфект. У Вукову пријеводу Новог завјета има и једног и другог облика големо мноштво, зацијело поради црквенославенскога текста, који их има такођер сву силу и којега се Вук држао као у многоме којечему другом, тако и у овоме. За Вуковим пријеводом Новога завјета повео се Даничић у своме пријеводу Старога завјета, те оне облике употребљава врло обилно. У осталим Вуковим дјелима (па и у његовим писмима и преписци) ријетки су - према Новом завјету - поменути облици, особито имперфект".
}

Употреба облика варира, дакле, с обзиром на жанровски састав и социјални статус текста/дискурса.

б) Кад је реч о другоме, Маретић тврди (1963: 620): „Када казује што је у прошлости, то може да буде приповиједање или приопћавање или јављање или спомињање." Маретић не дефинише нити појмовно одређује своје категорије, већ само наводи примере, по којима се може претпоставити да је реч о вербатолошки одредљивим врстама излагања (исп. и: Јовановић Симић, Симић 2015).

61),ААрист (и имперфект) у приповиједању за догађаје који су се догодили у прошлости, значи дакле исто што и хисторички презент и перфект...”: - Родитељи његови uђаху сваке године у Јерусалим о празнику пасхе. И кад му (тј. Исусу) би

\footnotetext{
${ }^{1}$ Подробније о томе в.: Јовановић Симић, Симић 2015.
} 
дванаест година, дођоше они у Јерусалим... - „Мјесто аориста (и имперфекта) у приповиједању може се свагда узети хисторички презент...” (Maretić 1963: 621).

б2) Приопћавање: - Снио сам, кнеже, да ти јашеш на коњу, пак загази у једно велико блато и заглиби се, а ја се деси близу тебе, а ти ме побрати, те те извади из блата.

б3) Јављање: - уједанпут оборе ватру из пушака и стану викати: бјежите! разби нас ајдук Вељко!

б4) Спомиъање: - ...ја сам вам неколико пута писао и говорио да се умирите и зулума оканите, а ви ме до данас не послушасте.

3. Једино што је могуће утврдити у разбору Маретићевих примера, јесте да је први узет из основног текста, а остала три из дијалошких реплика. Стога А. Мусић, нашавши се пред неразумљивим терминима, упрошћава Маретићеву схему сводећи је на три категорије, које назива 'стиловима', и изједначава их заправо са жанровским врстама израза: „Та су пак три стила ова: 1. стил народне пјесме, у којем се обилно употребљава исторички презент имперфективног глагола а скоро никако презент перфективног глагола, 2. стил Св. писма (свечани стил), гдје се не употребљава исторички презент ни имперфективног ни перфективног глагола, 3. стил народне приповијетке (исторички стил), гдје се слабо употребљава исторички презент имперфективног а врло обилно исторички презент перфективног глагола...” (Musić 1926-1927: I, 113). Мусић уз то разликује 'приповиједање' (П) од 'разговора' (Р), тј. говор певача, одн. причаоца, од говора личности о којима је у песми или прози реч.

4. Тиме су заправо препознати различити слојеви структура, али нису различито терминолошки обележени: 'приповиједање' и 'разговор' у ствари су дистинктни типови излагања; на другом крају лествице, 'приповијетка', 'пјесма' и 'Св. писмо' јесу производи излагања, и као такви могу се назвати ('микро-' или 'говорним') 'жанровима' (у домаћој терминологији 'родовима'); а квалитативна својства обележена терминима 'приповједачки', 'свечани' и 'историјски' - како рекосмо - јесу особине стилова. Укупна проблематика о којој је реч обухваћена је теоријским системом који смо ми назвали вербатолошким. У том контексту може се заиста говорити о жанровима, излагању и стиловима излагања као вербатолошким категоријама (Јовановић Симић, Симић 2015). Мусић даје квалификативне термине за 'стилове', који би се могли систематизовати као поетички, свечани (мајестетички) и историјски (касније назван приповедачки) ${ }^{2}$.

5. У оквирима које смо себи поставили у овом раду оправдано је, са гледишта Мусићеве класификације, говорити о 'приповједном', на једној страни, али и 'разговорном стилу' - на другој. Приповедање је, затим, праћено и описима, и баш је проблем односа међу приповедним и описним пасажима у народној приповеци актуелна тема о којој је могуће расправљати са различитих гледишта (Јовановић Симић, Симић 2015), а у том реду и са гледишта употребе временских облика. Ту долазе и подстицајни (императивни или сл.) искази јунака, те 'расудни' (експликативни, аргументативни) искази и приповедачеви и његових јунака, који се по не-

\footnotetext{
${ }^{2}$ Остављамо по страни однос приповедног текста према историјском у разграничењу међу функционалним стилским формацијама.
} 
опходности каткада јављају свуда, па и у народној причи: мисли и тумачења неких догађаја, изјаве о карактерима итд. Наш је задатак да размотримо у каквој су вези употреба глаголских облика и раслојавање текста по показаним трансверзалама.

\section{2. Преглед грађе}

1. Ваља одмах на почетку подсетити се на оно што Маретић и Мусић налазе: да основу народног причања чини 'хисторичка' (рекосмо: у каснијој српској терминологији приповедачка) употреба времена, нарочито презента, а да се у причама из Боке которске често уместо тих облика јавља аорист и имперфекат. Узећемо који пример из Вукове збирке (Вук 1969).

2. Прва је по реду приповетка 'Зла жена'. Анализираћемо најпре њен почетак:

Путовао некуд човек са женом, па ударе преко ливаде скоро покошене, онда човек рече: „Ала жено!, лијепо ти је ова ливада покошена!” А жена: „Зар ти је напало на очи, те не видиш да то није кошено, него стрижено!” А човек опет: „Бог с тобом, жено! како ће се ливада стрићи? То је кошено, ето видиш откоса".

а) Цео се исечак понаша заправо као јединствена широка исказна форма у коју су укључене побочне форме дијалошких реплика. Такав утисак добија се од тежње ка сажетости излагања, јер други и трећи приповедни исказ тако су деформисани, да су сведени на минимум: 'А жена', 'А човек опет'. У сваку од њих, у прву развијену ('Путовао некуд човек са женом, па ударе преко ливаде скоро покошене, онда човек рече'), као и у две помоћне, уметнута је по једна дијалошка реплика. Тако оквирне форме чине приповедни низ, а дијалошке реплике имају статус допунских јединица.

б) На приповедној линији употребљена су три глаголска облика, сваки различит од друга два. Сваки од њих или успоставља догађај у однос према времену говорења, или пак просто локализује радњу у већ оцртаном временском оквиру.

б1) Крњи перфекат 'путовао (некуд човек са женом)' издалека уводи слушаоца у причу тако што догађај описује као далеку неодређену прошлост чије су последице заправо почетни део сличице која настаје излагањем догађаја у низу облика који следе. Тако се садржај крњег перфекта показује као гранични моменат временског оквира описане ситуације која следи.

б2) За овим је приповедачки презент '(па) ударе (преко ливаде...)', који ту прошлост, заједно са скупом пратећих лексема развија у ширу ситуацију, и у ту ситуацију смешта радњу означену глаголом, одређујући је временски само као њен део.

63) Трећи употребљени глагол има облик аориста '(онда човек) рече', којим причалац динамизује излагање и унеколико појачава тонус приповедања, које је пре тога показивало тенденцију опадања. То је постигнуто тиме што аорист на једној страни попут презента локализује радњу у ситуацији о којој је реч, а на другој је усмерен према времену говорења, указујући да се догађаји дешавају у прошлости. Бирелационалност пређашњих времена условљава појачање приповедног тонуса.

в) Даљи ток приче карактеришу слаба приповедна линија и снажан тон дијалога. Дијалошке форме су описне по основном смислу, као такве истичу предмет о 
којем је реч - ливаду - и њену једну особеност, око које настаје распра: како је с ње скинута трава, која још стоји у откосима.

в1) Муж дивећи се истиче да је ливада 'покошена'. Обликом пасива више се упућује на резултат у оцртаној ситуацији у којој се води разговор него сам догађај који јој је претходио у неко неодређено време пре те ситуације. Излагање је делом описног, али делом и експликативног карактера: муж истиче особине 'ливаде' као факторе њеног стања после 'кошења'.

в2) Друга реплика главнином је слична првој: двоструким пасивом '(je) кошено' и '(је) стрижено' наглашава статику ситуације, док презент '(не) видиш' слабом динамичношћу основног глагола није у стању да разбије ту статику. Битно је да оба облика развијају слику и карактеришу је као истовремену са самим разговором (однос према времену приповедања потиснут је у позадину). Но почетак перфектом активним '(зар ти) је пало (на очи)', експресивним 'зар' и јаким пратећим лексемама - диктира врло снажан иницијални тон, који се затим одржава током целе реплике. И овде је у првом плану слика која припада ситуацији у којој се води разговор, а прошли догађај описан перфектом само је приказан као позадинска чињеница.

в3) Трећа реплика, са уводним експресивним изразом 'Бог с тобом', те упитним тоном и обликом футура '(како) ће се... стрићи?' узлеће тонски према некој врсти крешченда, а опис који следи ('То је кошено, ето видиш откоса') у ствари више је експликација него нарација, више је расудног него описног карактера, и у тој вербатолошкој врсти више подсећа на емфатичку персуазију него на аргументативни исказ. Временски односи на које упућују пасив и футур - готово су невидљиви, код пасива, или су сасвим невидљиви, код футура (он истиче модалну перспективу исказиву и потенцијалом - „Бог с тобом, жено, како би се ливада стригла?”). Експликација прераста у емфатичку констатацију.

3. Размотрићемо и наставак приче, чији је ток снажно ојачан на први поглед врло оскудним средствима:

И тако човек доказујући да је кошено, а жена, да је стрижено, сваде се, и човек удари жену, па јој стане викати да ућути; а жена пристане поред пута уз човека, па му унесе два прста под очи, и њима стрижући као ножицама, стане викати: „Стрижено! стрижено! стрижено!” Идући она тако поред пута, а не гледајући преда се, него човеку у очи и у своје стрицкање, нагази на некакву рупу, која је од озго била прекривена откосима, и у њу упадне.

а) У исечку пред нама преовлађује приповедачки начин излагања, а употребљена је само једна дијалошка интарзија, лишена реченичних обележја, и понављањем прерасла у експресијски високо потенциран градацијски низ: „Стрижено! стрижено! стрижено!"

б) Остали део попуњен је приповедним текстом. Интересантна је обличка ситуација, јер се - на главном правцу приче - углавном смењују прилог времена садашњег ('доказујући', 'стрижући', 'идући', 'гледајући') и приповедачки презент ('сваде се', 'удари', 'стане (викати)', 'пристане', 'унесе', 'нагази', 'упадне'). Видан моменат јесте жива дискурсна прогресија излагања, и по томе би се рекло да је динамика догађања једина основа његова. Али ако наш исечак у мислима спојимо са претходно наведеним у јединствену целину (коју они у приповеци и чине), онда видимо да је динамика у ствари ограничена оквирном ситуацијом коју оцртава почетна слика. И цела приповетка заправо као да се креће у датом оквиру. Зато је 
и могућа употреба презента за догађаје који се у том амбијенту описују. И ту је у ствари разлог и могућност за употребу приповедачког презента у српском језику уопште: он има локализацијску функцију јер смешта радњу у већ познати временски оквир.

в) Преостао је презентски облик '(стане викати) да ућути', који и на први поглед не стоји на главном трагу приповедања. Својим императивним значењем он сеже у постнарацијску сферу - означава дакле будућност у односу на време када се презент изриче.

4. Временски оквир је у народним приповеткама најчешће оцртан крњим перфектом, о чему сведочи почетак код низа приповедака Вукове збирке, нпр. 'Чардак ни на небу ни на земљи': „Био један цар, па имао три сина и једну кћер коју је у кафезу хранио и чувао као очи у глави”; - 'Немушти језик': „У некаква човека био један чобан који га је много година верно и поштено служио"; - 'Златна јабука и девет пауница' ,Био један цар па имао три сина и пред двором златну јабуку која за једну ноћ и уцвета и узре и неко је обере, а никако се није могло дознати ко”. Итд.

a) Тако у првом и другом наведеном случају за иницијалним крњим долази пуни перфекат. Рекло би се да крњи перфекат свој садржај износи у ослонцу на пуни, дакле да је 'Био један цар...', или '...био један чобан' ослоњено на потоње 'коју је хранио и чувао', или 'који га је... служио'. А нема потребе ни доказивати да је однос управо обрнут: пуни перфекат развија слику чији оквир поставља крњи облик, с тим што отвара перспективу и према приповедном времену као прошли догађај.

б) У трећем случају за крњим перфектом следују презенти, који свој садржај једноставно смештају у дати временски оквир као опште чињенице иза којих се крију поновљени догађаји. Но за презентима долази перфекат '(никако) се није могло (знати)', који такође има локализацијски карактер јер смешта свој садржај у оцртани оквир као и презент, али упућујући да се ради о прошлости у односу на време приповедања.

5. Није наравно истина да је крњи перфекат једини компетентан да да̂ оквир за ситуацију догађања. Ту улогу може имати и пуни перфекат, као нпр. у приповеци 'За што у људи није табан раван': „Кад су ђаволи отпали од Бога и утекли на земљу, онда су и сунце однијели са собом, па га ђаволски цар набио на копље и носио на рамену"; или 'Побратимски дарови': „Причају људи да је у стара времена био некакав силан чоек који се никад Богу не мољаше, ни у цркву идаше, нити се по закону исповиједаше ни причешћиваше, него у свака безакоња упадаше, да је цијели град од њега на јадима био. Од више силе није хтио женити се као што Господ Бог заповиједа, него науми да вјенча аждају како ће више зло чинити, и упути се у некаку пустињу ђе су страшна језера, али не погоди пута, и тако га ноћ стигне те у некакој пећини заноћи".

а) Врло је карактеристичан први наведени случај. Пуни перфекти у низу заправо упућују на низ догађаја у сукцесији без уоквирења ситуације: 'отпали', 'утекли', 'однијели', 'набио'. Напредовање дискурзије је стално, све до перфекта имперфективнога глагола, последњег облика у низу, који отвара догађаје у ширину и формира обрисе ситуације: 'и носио на рамену'.

б) Последњи случај је компликован уводном реченицом 'Причају људи...' - која у ствари активира приповедно време као оријентациони моменат. Следи и временска одредба 'у старо време', која тематику приче карактерише као прошлу 
- а пуни перфекат '(да) је био' потврђује ту чињеницу и започиње излагање о тематици и коначно оцртава оквир ситуације збивања. Низ имперфеката описује скуп догађаја који један према другоме нису временски оријентисани, већ као на слици стоје један поред другог. Ако је могуће дочарати статику излагања, дакле изложити догађаје помоћу динамичких речи, али на начин који искључује прогресију, онда је то овде постигнуто. На крају као нека врста тумачења долази перфект који описује последице понашања јунака приче у расудном стилу.

5. Ми горе говорасмо о унапред датом временском оквиру који је оцртан перфектом, и у који бива смештан догађај или догађаји локализацијским начином описани, пре свега приповедачким презентом или имперфектом, а некад и перфектом. Као деманти такве тврдње може се, међутим, навести више примера где се на самом почетку приповедног низа употребљава презент. Нпр. у приповеци 'Међедовић', коју ћемо описати нешто шире, почетак гласи:

У некакоме селу пођу жене у планину да траже дивљега броћа, и тако врљајући по планини једна од њих зађе и дође пред једну пећину из које изиђе међед те је ухвати и одведе унутра; и онђе живећи с њоме, жена затрудни и роди мушко дијете. Пошто дијете мало поодрасте, жена се некако украде и утече у село својој кући. Међед је једнако којешта доносио и дијете хранио, као и прије му матер. Кад дијете нарасте повелико, оно навали да иде из пећине у свијет. Међед га стане од тога одвраћати говорећи му да је он још млад и нејак, а у свијету има злијех звјерова који се зову људи, па ће га убити. И тако се дијете мало поумири и остане у пећини. Послије некога времена дијете опет навали да иде у свијет, и кад га међед није могао друкчије одвратити, а он га изведе пред пећину под једну букву, па му рече: „Ако ту букву можеш ишчупати из земље, онда ћу те пустити да идеш у свијет, ако ли не можеш, још ваља да сједиш код мене”. Дијете спопадне букву, па повуци тамо повуци овамо, али не може да је ишчупа; онда се опет врати с оцем у пећину...

Текст који смо навели вербатолошки је много компликованији од осталих горе навођених, и далеко сложенији него што би се очекивало према ономе што се мисли о народној приповеци као типу излагања који је врло прост по саставу.

a) Најпре нам ваља утврдити улогу почетног сегмента. Чини га исказ који се састоји из два доста јасно разграничена дела. Први део, низ приповедачких презената - описује временски неодређени низ догађаја који снагом сопственог израза ако не оцртавају ситуацију, онда ипак стварају утисак јединствене слике у чијем се оквиру нижу сукцесивни догађаји: 'пођу', 'зађе', 'дође', 'ухвати', 'одведе'. Други део тога сегмента: „...и онђе живећи с њоме...” није временски, него смисаоно разграничен од првог, и ипак не чини с њим јединство, већ засебну целину, временски без обзира на то мање-више јединствену.

б) И други сегмент је разломљен у два дела, а од првога је одељен временском дистанцом која је обележена прилошким везником 'пошто'. Опет би оба дела сегмента била временски јединствена да није прилога 'прије', којим је постављена граница. Пошто су временски односи регулисани прилошким речима, улога презента се сужава на локализацију догађаја у њиховом сплету.

в) Трећи сегмент почиње од временске реченице 'Кад дијете нарасте повелико'. Али поред даљег развоја догађаја, дакле приповедног стила излагања, долазе расудни искази који заустављају напредовање приче, и остављају утисак преласка на апстрактни ниво аргументативног типа излагања. Нпр. 'оно навали да иде из пећине у свијет', сем динамичких црта које долазе од глагола 'навалити' и 'ићи', садржи и смисаоне елементе подстицајности, боље рећи самоафирмације. И поступак од- 
враћања који предузима отац припада истом типу излагања. Даљи ток приче састоји се од приповедних и расудних елемената који се узајамно смењују, и тако омогућују напредовање, уз отварање видика према апстрактним сферама излагања.

Текст углавном садржи презентске облике, али повремено и друге, који обезбеђују варијацију излагања уносећи побочне временске моменте у општу ситуацију. Тако перфекат 'доносио је' и 'хранио', као што смо и горе видели, смештајући свој садржај у дати временски оквир, садржи значење прошлости у односу на приповедно време. Футур у реченици 'пак ће га убити' за ослонац има говор јунака приче, у односу на који се његов садржај одређује као будући, боље постериоран. Исто вреди и за облик у реченици 'онда ћу те пустити'.

6. После горњих анализа биће нам лакше да схватимо положај и улогу имперфекта као иницијалног облика у приповеци. Нека за пример послужи приповетка 'Дјевојка цара надмудрила':

Један сиромах живљаше у једној пећини и немаше ништа до једну шћер, која бијаше много мудра и иђаше свуда у прошњу, па и оца свога учаше како ће просити и мудро говорити. Дође једном сиромах к цару да му штогођ удијели; цар га упита окле је и ко га је научио мудро говорити. Ови му одговори окле је и како га је шћер научила...

а) Разумети односе у овом исечку могуће је тек у поређењу са случајевима презента у истој позицији. Рекли смо да се презентом у почетним редовима текста приповетке ствара привид слике једино груписањем тих облика у скуп статичких описа који догађање приказују као јединствени скуп догађаја. Слично је у ствари и са имперфектом, с тим што се њиме отвара и релација према времену приповедања, којом се упућује да догађаји овоме претходе, да припадају прошлости. У нашем случају сем приказивања реалних дешавања - 'живљаше', 'иђаше', 'учаше' - имамо и 'немаше (ништа)', 'бијаше (много мудра)', што као расудно излагање појачава осећај сликовитости, и доприноси уоквирењу догађаја као јединствене ситуације.

б) Друге две исказне форме претежно садрже презенте 'дође (цару)', 'упита (га)', 'одговори му', '(окле) је', што их карактерише као локализационе форме које упућују на догађаје временски уоквирене претходно описаном ситуацијом. Остали облици нису на линији приповедања, већ представљају побочне рукавце. Футур '(како) ће просити (и мудро) говорити' са ослонцем на време када говори јунак приповетке, дакле на општу ситуацију оцртану облицима на главном правцу приче - означава будућност. Слично је и са перфектом у реченици 'ко га је научио', с тим што је овде у питању претхођење ситуацији.

\section{3. Закључак}

1. Нововремене студије о употреби глаголских временских облика не излазе из оквира реченице, тј. конкретне употребе форми, као и основне ћелије у којој се употреба дешава. У нашим вербатолошким испитивањима (Јовановић Симић, Симић 2015) показало се, међутим, да је за пуну спознају чињеница о тој теми неопходно у обзир узети најпре (микро)жанровске форме, као и остале вербатоло- 
шке категорије, нпр. стилске врсте 3 излагања и функционално стилске особености текстова. На трагу тих истраживања, као њихови зачетници који нису наишли на разумевање својих савременика, нашли су се старији хрватски филолози Т. Маретић (1963) и А. Мусић (1927-1927), који између осталог препознају разлике међу 'стиловима'.

2. Анализе које смо обавили показују да су врсте излагања, било да се ради о жанровским или функционално стилским особинама њиховим - у тесној вези са употребљеним временским облицима. Колико показане особености излагања утичу на употребу временских глаголских облика, исто толико и њихове особености зависе од тога.

3. Ми смо пратили облике углавном у иницијалним пасажима приповедака јер се ту најбоље огледају значењске особености и улога глаголских облика, и онима који долазе непосредно за овима. Није било могућности да на овако ограниченом простору ширимо истраживање и на друге делове приповедног текста, али није то ни прека потреба да би се утврдиле релевантне чињенице. А утврдили смо да је најчешћи случај када глаголски облици уоквирују временску ситуацију, пре свега у почетним пасажима приче - управо крњи перфекат као облик за неодређену прошлост, који дозвољава скретање пажње на оно што следи по догађају (мање или више као његова последица). Тиме је обележена почетна граница ситуације у којој се развијају догађаји, и у којој се често формира слика као амбијент према којем се временски управљају употребљени облици.

4. Ти облици који представљају средишњи део ситуације по правилу су приповедачки презент - облик са локализацијском функцијом - или имперфекат, који локализацијску функцију комбинује са релационом, тј. са указивањем на прошлост у односу на време говорења о догађају. Ако ову потоњу улогу преузима перфекат, он поред релационог преузима и значење локализационо, и тада функционише слично имперфекту.

5. Све што рекосмо дешава се на тзв. главном правцу приповедања. Оно што налазимо на побочним смеровима углавном је срачунато на допуну и прецизирање приче. Дијалошке форме у својој позицији чине побочне елементе приче, али дозвољавају ширење у приповедни тип излагања.

6. Утврдили смо, на крају, да постоје приповедни, описни, експликацијски, аргументативни, подстицајни и сл. стилски обележени начини излагања - и да су у вези са различитим значењима личних глаголских облика.

7. На крају, глаголски облици играју врло важну улогу у изградњи језичких комуникативних форми, и одређују њихове особине.

\section{Литература}

Јовановић Симић Ј., Симић Р. 2015. Вербатологија. Лингвистичке основе науке о вербализачији света. Београд: НДСЈ, Јасен, 2015.

Maretić T. Gramatika hrvatskoga ili srpskoga književnog jezika. Zagreb: Matica hrvatska, 1963.

\footnotetext{
${ }^{3}$ Исп. и: Симић 2001; Симић 2009.
} 
Musić A. „Gnomički aorist u grčkom i hrvatskom jeziku.” Rad Jugoslavenske akademije znanosti, 112 (1892).

Musić A. „Zum Gebrauche des Praesens verbi perf. im Slavischen.” Archiv für slavische Philologie, 24 (1902).

Мусић А. „Прилози науци о употреби времена у српскохрватском језику I/II/III.” Глас СКА. N. CXXI. - Drugi razr. 66/1926, стр. 109-173; CXXIII. - Drugi razr. (67/1927): стр. 69-119; CXXVI. - Drugi razr. (69/1927): стр. 1-59.

Musić A. „Preterit futura u indoevropskim jezicima.” Rad Jugoslavenske akademije znanosti, 243 (1932).

Musić A. „Slovenski efektivni prezent.” Rad Jugoslavenske akademije znanosti, 253, 1935.

Симић Р. „Глаголска времена у зависним реченицама.” Наш језик, XV (1966): 1-2, стр. 1-57; 3-4, стр. 121-157.

Симић Р. Општа стилистика. Београд: НДСЈ, Јасен, 2001.

Симић Р. „Нормативни и употребни статус футуроида 'ћу/ћеш...+ да + презент'.” Научни састанак слависта у Вукове дане, књ. 38, св. 1 (2009): стр. 51-55.

\section{Извори}

Караџић В. С. Српске народне приповијетке. Београд: Просвета, 1969.

Jelena J. Jovanović Simić

STRUCTURE AND FUNCTION OF TIME FORMS IN THE NATIONAL STORY

Summary

The author in this study shows that not only the sentences, in which the personal verb form forms the core, but also the wider textual forms: genres and modes of exposure (as well as functionally stylistic forms) are of significance for the study of the nature of verbal times. From this point of view, an analysis of a number of folk tales was analyzed and their role in the construction of textual forms and stylistic features was monitored.

Key words: verbative, style, folk narrative, verbal form, time form. 